\title{
Penentuan retensi nitrogen dan energi metabolis kulit pisang raja (Musa paradisiaca) fermentasi dengan Rhizopus oligosporus pada ransum broiler
}

\author{
M.N. Kalalo, F.R. Wolayan*, M.R. Imbar, H. Liwe \\ Fakultas Peternakan Universitas Sam Ratulangi ,Manado 95115 \\ Korespondensi (corresponding author): feny_wolayan@unsrat.ac.id
}

\begin{abstract}
ABSTRAK
Kulit pisang merupakan limbah yang sangat potensial dijadikan sebagai pakan karena jumlahnya yang melimpah dan mempunyai nutrien yang dibutuhkan ternak. Penelitian ini bertujuan untuk mengetahui konsumsi protein, nilai retensi nitrogen $(\mathrm{RN})$ dan nilai energi metabolis terkoreksi nitrogen (AMEn) ransum broiler yang mengandung tepung kulit pisang raja tanpa fermentasi dan ransum broiler produk fermentasi dengan kapang Rhizopus oligosporus. Penelitian ini dilakukan dengan menggunakan 20 ekor ayam broiler strain Arbor Acres CP 707 umur 5 minggu. Rancangan yang digunakan adalah Uji-t student yang terdiri dari 2 perlakuan, masing-masing perlakuan terdiri dari 10 ekor ayam broiler sebagai ulangan. Ransum yang digunakan pada penelitian ini yaitu ransum yang mengandung tepung kulit pisang raja tanpa fermentasi dan ransum yang mengandung tepung kulit pisang raja produk fermentasi dengan kapang Rhizopus oligosporus. Hasil analisis keragaman menunjukan bahwa perlakuan antara tanpa fermentasi dan fermentasi berbeda nyata terhadap konsumsi protein $(\mathrm{P}<0,05)$, retensi nitrogen berbeda nyata $(\mathrm{P}<0,05)$ dan terhadap nilai energi metabolis berbeda nyata $(\mathrm{P}<0,05)$. Hasil uji $\mathrm{T}$-student untuk nilai konsumsi protein nilai retensi nitrogen menunjukan bahwa perlakuan tanpa fermentasi $63,59 \%$ dan $71.87 \%$ produk fermentasi dengan kapang Rhizopus oligosporus. Nilai energi metabolis pada perlakuan tanpa fermentasi 2336.6 $\mathrm{Kcal} / \mathrm{kg}$ dan $2732.4 \mathrm{Kcal} / \mathrm{kg}$ pada produk fermentasi dengan kapang Rhizopus oligosporus. Berdasarkan hasil penelitian ini dapat disimpulkan bahwa penggunaan kulit pisang raja produk fermentasi dengan kapang Rhizopus oligosporus dalam ransum broiler dapat meningkatkan konsumsi protein, retensi nitrogen, dan energi metabolis ayam broiler.
\end{abstract}

Kata kunci: kulit pisang raja,fermentasi, Rhizopus oligosporus, ayam broiler.

\begin{abstract}
DETERMINATION OF NITROGEN RETENTION AND METABOLIC ENERGY OF BANANA PEELS (Musa paradisiaca) FERMENTATION WITH Rhizopus oligosporus ON BROILER RANSOM. Banana peel is a waste that has the potential to be used as feed because it is abundant and has the nutrients needed by livestock. This study aims to determine protein consumption, nitrogen retention value (RN) and nitrogen-corrected metabolic energy (AMEn) value of broiler rations containing unfermented plantain peel flour and fermented broiler rations with Rhizopus oligosporus mold. This research was conducted using 20 broilers of strain Arbor Acres CP 707 aged 5 weeks. The design used was Student's t-test which consisted of 2 treatments, each treatment consisting of 10 broilers as replications. The rations used in this study were rations containing plantain peel flour without fermentation and rations containing fermented plantain peel flour with Rhizopus oligosporus mold. The results of the analysis of diversity showed that the treatment between no fermentation and fermentation was
\end{abstract}


significantly different for protein consumption $(\mathrm{P}<0.05)$, nitrogen retention was significantly different $(\mathrm{P}<0.05)$ and the value of metabolic energy was significantly different $(\mathrm{P}<0.05)$. The T-Student test results for the protein consumption value of nitrogen retention values showed that the treatment without fermentation was $63.59 \%$ and $71.87 \%$ fermented products with Rhizopus oligosporus mold. The metabolic energy values in the treatment without fermentation were $2336.6 \mathrm{Kcal} / \mathrm{kg}$ and $2732.4 \mathrm{Kcal} / \mathrm{kg}$ in fermentation products with Rhizopus oligosporus mold. Based on the results of this study it can be concluded that the use of fermented plantain peel products with Rhizopus oligosporus in broiler rations can increase protein consumption, nitrogen retention, and metabolic energy of broiler chickens.

Key words: plantain peel, fermentation, Rhizopus oligosporus, broiler chicken.

\section{PENDAHULUAN}

Unggas merupakan komoditas ternak yang produknya banyak dikonsumsi oleh masyarakat. Peternakan unggas merupakan subsektor yang diandalkan untuk memenuhi kebutuhan protein hewani masyarakat, karena mampu menghasilkan protein hewani dengan bentuk daging dalam waktu yang relatif singkat (Sugiyono et al., 2015). Hal ini pula yang mendukung industri broiler di Indonesia sangat berkembang pesat. Namun demikian kondisi tersebut tidak lepas dari permasalahan pakan.

Pakan mempunyai proporsi terbesar dalam usaha peternakan, yakni sekitar 60$70 \%$ dari total biaya produksi. Saat ini pakan yang digunakan dalam budidaya broiler masih bergantung pada pakan pabrikan yang sebagian besar bahan pakan penyusun ransum masih diimpor, sehingga biaya pakan sangat tinggi. Kondisi ini para peternak melakukan berbagai usaha untuk meminimalkan biaya pakan, alternatif yang dapat dilakukan untuk mengatasi kendala tersebut yaitu menggali potensi bahan lokal dengan memanfaatkan sumber bahan lokal yang melimpah, murah harganya, tidak bersaing dengan kebutuhan manusia, tersedia terus menerus dan mengandung nutrien yang dibutuhkan ternak (Suprayudi et al., 2011). Salah satu bahan baku untuk dijadikan pakan alternatif adalah memanfaatkan limbah kulit pisang raja segar.

Kulit pisang raja merupakan limbah produk pangan yang dapat menyebabkan pencemaran lingkungan, namun cukup potensial dijadikan bahan pakan alternatif penyusun ransum ayam broiler (Nuramanah et al., 2012). Kandungan nutrien kulit pisang raja yaitu protein kasar $7,64 \%$, lemak $3,02 \%$, serat kasar $17,30 \%$ serta energi bruto $3621,25 \mathrm{Kcal} / \mathrm{kg}$ (Mokoolang et al., 2017). Berdasarkan kandungan nutrien, maka kulit pisang raja dapat ditingkatkan kualitasnya melalui teknologi fermentasi. Teknologi fermentasi banyak dilakukan untuk peningkatan nilai gizi bahan pakan lokal atau asal limbah, misalnya melalui fermentasi dengan menggunakan Rhizopus oligosporus. Miselium yang tumbuh dipermukaan tempe diambil dengan cara rnengiris permukaan tempe tersebut, kemudian irisan permukaan yang diperoleh dijemur, digiling dan digunakan sebagai kapang Rhizopus oligosporus (Dewi dan Aziz, 2011). Fermentasi kulit pisang raja menggunakan kapang Rhizopus oligosporus dengan dosis inokulum $0,4 \%$ serta lama fermentai 96 jam dapat meningkatkan nilai protein $7,64 \%$ menjadi 12,13\% (meningkat $60,91 \%$ ). Penelitian Tepung kulit pisang raja tanpa fermentasi dapat digunakan sebesar $15 \%$ dalam ransum broiler (Djapili et al., 2016). Untuk menguji kualitas pakan dilakukan uji biologis dengan mengukur kecernaan. 


\section{MATERI DAN METODE PENELITIAN}

Penelitian ini dilaksanakan di kandang Laboratorium Basah Fakultas Peternakan Universitas Sam Ratulangi Manado, berlangsung pada tanggal $18 \mathrm{Mei}$ 2018 sampai tanggal 28 Mei 2018. Penelitian ini menggunakan 20 ekor broiler strain Arbors Acres CP 707 berumur 5 minggu dengan berat badan berkisar 1.202 - 1.544 gram, dibagi dalam dua perlakuan, yang masing-masing perlakuan terdiri dari 10 ekor ayam sebagai ulangan. Bahan pakan yang digunakan dalam penelitian ini yaitu kulit pisang raja tanpa fermentasi (PTF), kulit pisang raja fermentasi dengan kapang Rhizopus oligosporus (PF), jagung kuning, bungkil kelapa, tepung ikan, tepung kedelai, dedak halus, dan topmix. Komposisi zat-zat makanan dan energi metabolis bahan pakan penyusun ransum tercantum pada Tabel 1, Tabel 2 mencantumkan komposisi bahan makanan ransum percobaan, sedangkan Tabel 3 mencantumkan komposisi zat makanan dan energi bruto ransum percobaan.

\section{Pembuatan Inokulum Ragi Tempe (Rhizopus Oligosporus)}

Sebanyak 320 gram ragi tempe diinokulasikan dengan 80 gram kulit pisang raja yang sudah dijadikan tepung, disimpan dalam toples yang sudah disterilkan supaya tidak terkontaminasi dengan mikroorganisme yang lain.

Tabel 1. Komposisi Zat Makanan dan Energi Bruto Bahan pakan Penyusun Ransum.

\begin{tabular}{|c|c|c|c|c|c|c|c|}
\hline Bahan Makanan & $\begin{array}{l}\text { Protein } \\
(\%)\end{array}$ & $\begin{array}{l}\text { Serat } \\
\text { Kasar } \\
(\%)\end{array}$ & $\begin{array}{l}\text { Lemak } \\
(\%)\end{array}$ & $\begin{array}{l}\mathrm{Ca} \\
(\%)\end{array}$ & $\begin{array}{l}\mathrm{P} \\
(\%)\end{array}$ & $\mathrm{Abu}$ & $\begin{array}{l}\text { Energi } \\
\text { Bruto } \\
\text { (Kcal/Kg }\end{array}$ \\
\hline Kulit Pisang Raja*** & 7,64 & 17,50 & 3,02 & 0,53 & 0,25 & & 3621,25 \\
\hline Kulit pisang raja fermentasi*** & 12,13 & 14,12 & 2,50 & 0,74 & 0,56 & & 3441 \\
\hline Jagung* & 9,42 & 2,15 & 5,17 & 0,22 & 0,60 & & 3729,12 \\
\hline Tepung Kedelai** & 40,38 & 6,56 & 9,91 & 0,24 & 0,58 & 15,13 & 3062.25 \\
\hline Bungkil Kelapa* & 24,74 & 15,02 & 9,36 & 0,11 & 0,47 & & 4094.69 \\
\hline Dedak* & 13,44 & 6,35 & 6,07 & 0,19 & 0,73 & 6,95 & 3369.38 \\
\hline Tepung Ikan* & 58,52 & 2,95 & 13,90 & 7,04 & 3,67 & 10,33 & 4338 \\
\hline Minyak** & - & - & 100 & - & - & & 8812 \\
\hline Top Mix** & - & - & - & 5,38 & 1,44 & & \\
\hline
\end{tabular}

Sumber. * Dengah et al. (2013); **Kowel (2007); ***Mokoolang et al. (2017).

Tabel 2. Komposisi Bahan Makanan Ransum Percobaan.

\begin{tabular}{lll}
\hline \multirow{2}{*}{ Bahan Ransum (\%) } & \multicolumn{2}{c}{ Perlakuan } \\
\cline { 2 - 3 } & PTF & PF \\
\hline Jagung & 48,45 & 48,45 \\
Kulit Pisang Raja & 8,55 & 8,55 \\
Tepung Kedelai & 13,00 & 13,00 \\
Bungkil Kelapa & 6,00 & 6,00 \\
Tepung Ikan & 14,00 & 14,00 \\
Dedak & 8,00 & 8,00 \\
Top Mix & 0,50 & 0,50 \\
Minyak Kelapa & 1,00 & 1,00 \\
Total & 100 & 100 \\
\hline
\end{tabular}


Tabel 3. Komposisi Zat Makan dan Energi Ransum Percobaan.

\begin{tabular}{lll}
\hline Zat-zat makanan & PTF & PF \\
\hline Protein $(\%)$ & 21,44 & 21,83 \\
Serat kasar $(\%)$ & 5,23 & 4,90 \\
lemak $(\%)$ & 7,04 & 7,00 \\
Ca $(\%)$ & 1,19 & 0,98 \\
P (\%) & 1,21 & 1,03 \\
Energi Bruto (Kcal/kg) & 3782,13 & 3707,72 \\
\hline
\end{tabular}

Dihitung berdasarkan Tabel 1, Tabel 2, dan Tabel 3.

\section{Prosedur Fermentasi Kulit Pisang Raja (Musa paradisiaca)}

Kulit pisang yang telah dipilih, dicuci dengan air bersih kemudian dipotong $\pm 2 \mathrm{~cm}$. Kulit pisang yang telah dipotong dimasukkan dalam plastik, kemudian dimasukkan dalam alat pengukus setelah air mendidih selama 15 menit pengukusan berfungsi untuk mematikan mikroba pathogen pada kulit pisang. Tebarkan kulit pisang raja yang telah dikukus diatas nampan dan diangin-anginkan sampai dingin. Inokulasikan dengan inokulum 3,2 gram dari 800 gram kulit pisang raja kemudian campur kulit pisang dengan inokulum sampai homogen, masingmasing dimasukan dalam kantong plastik yang sudah dilubangi ke 2 sisinya untuk mendapatkan kondisi aerob. Inkubasi dalam suhu ruang $\left(25-28^{\circ} \mathrm{C}\right) 72$ jam (3 hari). Kemudian keringkan semua perlakuan dengan menggunakan oven pada suhu $60^{\circ} \mathrm{C}$ selama 3 hari (sampai diperoleh berat konstan) selanjutnya digiling sampai halus.

\section{Prosedur Penelitian}

Mempersiapkan peralatan penelitian, tempat pakan, tempat minum dicuci bersih. Kemudian kandang disterilkan menggunakan bahan kimia desinfektan kuat (formalin 0,5\%) membasmi serangga dan mikroba (virus, bakteri, jamur, lumut, ganggang). Broiler sebanyak 20 ekor yang sudah ditimbang berat badan berkisar $1.202-1.544$ gram kemudian ditempatkan pada kandang yang sudah diberi label perlakuan secara acak ditempatkan masing-masing 1 ekor ayam broiler, kemudian diberikan pakan dan air minum disediakan secara ad libitum dan vitastress.

Penimbangan dilakukan secara rutin pada setiap pemberian ransum yang diberikan, sisa ransum, berat wadah penampung ekskreta, dan berat kering ekskreta. Masa adaptasi selama 7 hari, pada hari ketujuh masa adaptasi ayam dipuasakan selama 12 jam dengan tetap diberi air minum. Setelah puasa 12 jam broiler diberi ransum penelitian sesuai perlakuan dan diberi wadah aluminium foil berbentuk kotak untuk menampung ekskreta. Wadah ekskreta di ambil setelah 24 jam untuk koleksi ekskreta, dilakukan selama 3 kali berturut-turut hingga hari ke4 dan disemprot asam borat 5\% setiap 3 jam untuk mengikat nitrogen. Selama tahap perlakuan dilakukan pencatatan pertambahan bobot badan dan konsumsi ransum untuk mendapatkan data konsumsi protein. Ekskreta yang terkumpul dikeringkan dengan sinar matahari kemudian dilanjutkan dikeringkan didalam oven dengan suhu $60^{\circ} \mathrm{C}$ selama 24 jam. Ekskreta kering digiling halus, ditimbang dan dianalisis nutrien.

\section{Variabel yang diukur}

Variabel yang diukur pada penelitian ini terdiri dari:

\section{Konsumsi Protein}

Konsumsi protein yaitu jumlah protein yang dikonsumsi oleh ayam. Konsumsi protein dinyatakan dalam satuan gram, dihitung dengan rumus menurut Tillman et al. (1998) sebagai berikut:

Konsumsi protein $(\mathrm{g})=$ Konsumsi pakan (g) x Kadar PK ransum (\%) 


\section{Retensi Nitrogen (N) \\ Pengukuran dan perhitungan nilai retensi $\mathrm{N}$ dan energi metabolis terkoreksi $\mathrm{N}$ (Zarei, 2006):

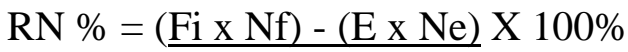

$$
\text { (Fix Nf) }
$$

Keterangan:

RN : Retensi nitrogen (\%)

Fi : Pakan yang dikonsumsi (g)

Nf : Nitrogen Pakan (\%)

E : Jumlah Ekskreta (g)

$\mathrm{Ne} \quad$ : Nitrogen Ekskreta (\%)

Energi Metabolis (AMEn)

$A M E n=($ Fi $\times$ GEf $)-(E \times$ GEe $)-($ NR $\times$ K) $X 100$ $\mathrm{Fi}$

Keterangan :

AMEn : Energi Metabolis Semu yang dikoreksi dengan Retensi Nitrogen (Kcal/Kg)

NR : Retensi Nitrogen (\%)

$\mathrm{Fi}$ :Banyaknya pakan yang dikonsumsi

E : Jumlah Ekskreta

GEf : Energi Bruto Pakan (Kcal/kg)

GEe : Energi Bruto Ekskreta (Kcal/kg)

K : Konstanta Koreksi untuk Nilai

Energi Nitrogen yang diretensi (8,22

$\mathrm{Kcal} / \mathrm{kg}$ untuk setiap gram nitrogen)

\section{Analisis Statitika}

Untuk menguji pengaruh perlakuan terhadap parameter yang diukur akan menggunakan Uji t-student (Steel dan Torrie, 1995):

$\mathrm{t}=\frac{\mathrm{Y}}{\mathrm{Sy}}=\frac{\mathrm{Y}-\mu}{------}$

Keterangan :

Tabel 4. Rataan Nilai Konsumsi Protein, Retensi Nitrogen dan Energi Metabolis Ransum Menggunakan Tepung Kulit Pisang Raja Tanpa Fermentasi dan Produk Fermentasi

\begin{tabular}{lcc}
\hline \multirow{2}{*}{ Parameter } & \multicolumn{2}{c}{ Perlakuan } \\
\cline { 2 - 3 } & PTF & PF \\
\hline Konsumsi protein $(\mathrm{g})$ & $14.06^{\mathrm{a}}$ & $15.56^{\mathrm{b}}$ \\
Retensi nitrogen $(\mathrm{g})$ & $63.59^{\mathrm{a}}$ & $71.87^{\mathrm{b}}$ \\
AMEn (Kcal/kg) & $2336.6^{\mathrm{a}}$ & $2732.4^{\mathrm{b}}$ \\
\hline
\end{tabular}

Keterangan: Superskrip yang berbeda pada baris yang sama menunjukkan adanya perbedaan yang nyata $(\mathrm{P}<0,05)$

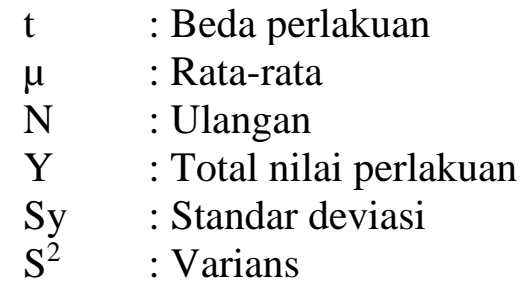

\section{HASIL DAN PEMBAHASAN}

Rataan nilai konsumsi protein, retensi nitrogen $(\mathrm{RN})$ dan energi metabolis terkoreksi nitrogen (AMEn) ransum menggunakan tepung kulit pisang raja disajikan pada Tabel 4.

\section{Pengaruh Perlakuan Terhadap Nilai Konsumsi Protein Ransum Broiler}

Rataan konsumsi protein ransum per ekor pada perlakuan menggunakan tepung pisang raja tanpa fermentasi sebesar 14,06 gram dan produk fermentasi sebesar 15,56 gram. Berdasarkan uji $t$-student menunjukan bahwa penggunaan tepung kulit pisang raja produk fermentasi berbeda nyata $(\mathrm{P}<0,05)$ dibandingkan dengan tanpa fermentasi. Hasil penelitian ini sejalan dengan (Winedar, 2006) yang melaporkan bahwa konsumsi protein pakan broiler sebesar 13,49 g/ekor/hari sampai dengan 16,79 g/ekor/hari pada umur 5 minggu. Demikian juga Mide (2016) melaporkan bahwa konsumsi protein ayam broiler sampai umur 6 minggu sebesar 124,49 g/ekor/minggu. Faktor yang mempengaruhi konsumsi protein adalah konsumsi ransum dan kandungan protein kasar ransum. tanpa fermentasi dan produk fermentasi 
Gultom dan Supratman (2014) menyatakan bahwa konsumsi protein yang tinggi akan mempengaruhi asupan protein pula ke dalam daging dan asam-asam amino tercukupi di dalam tubuhnya sehingga metabolisme sel-sel dalam tubuh berlangsung secara normal. Hal ini sesuai dengan pendapat Pramana (2012) yang menyebutkan bahwa asupan protein dipengaruhi oleh jumlah konsumsi ransum. Tillman et al. (1998) bahwa kecernaan protein kasar tergantung pada kandungan protein kasar dalam ransum.

\section{Pengaruh Perlakuan Terhadap Nilai Retensi Nitrogen Ransum Broiler}

Rataan nilai retensi nitrogen ransum broiler dalam penelitian ini yaitu 63,59\% tepung pisang raja tanpa fermentasi dan produk fermentasi $71,87 \%$. Berdasarkan uji t-student menunjukan bahwa penggunaan tepung kulit pisang raja produk fermentasi dalam ransum broiler berbeda nyata $(\mathrm{P}<0,05)$ dibandingkan dengan tanpa produk fermentasi.

Hasil penelitian ini sejalan dengan Wahju (2004) melaporkan bahwa protein yang diretensi oleh ayam pedaging adalah $67 \%$ dari protein ransum yang dikonsumsi. Hasil penelitian yang telah dilakukan retensi nitrogen ransum produk fermentasi lebih tinggi dari pada produk tanpa fermentasi, ini membuktikan bahwa ransum produk fermentasi menunjukkan respon positif pada ayam broiler terhadap retensi nitrogen. Hal ini menggambarkan bahwa dalam proses fermentasi Rhizopus oligosporus menghasilkan enzim yang dapat meningkatkan protein.

Wahju (2004) mengemukakan bahwa retensi nitrogen dipengaruhi oleh beberapa faktor diantaranya daya cerna protein, kualitas protein, dan imbangan zat-zat makanan dalam ransum. Menurut Ewing (1963) yang disitasi oleh The et al. (2017) menyatakan bahwa meningkatnya protein dalam ransum dapat menurunkan $\mathrm{RN}$ dikarenakan sebagian protein digunakan untuk memenuhi kebutuhan energi. Hal ini membuktikan bahwa proses fermentasi kulit pisang raja menggunakan Rhizopus oligosporus dapat meningkatkan kualitas protein, dan memiliki daya cerna yang tinggi dengan menurunnya kandungan serat kasar maka nilai retensi nitrogen meningkat. Mokoolang et al. (2017) menyatakan bahwa fermentasi kulit pisang raja menggunakan Rhizopus oligosporus dengan dosis inokulum $0,4 \%$ serta lama fermentasi 96 jam meningkatkan protein kasar sebesar 60,91\%. Demikian juga pernyataan Achi (2005) dan Buckle et al. (2007) bahwa bahan pakan yang telah difermentasi mempunyai daya cerna lebih tinggi karena protein, lemak dan polisakarida telah dihidrolisis mikroba selama proses fermentasi berlangsung.

\section{Pengaruh Perlakuan Terhadap Nilai Energi Metabolis (AMEn) Ransum Broiler}

Rataan nilai energi metabolis hasil penelitian ini yaitu $2336.6 \mathrm{Kcal} / \mathrm{kg}$ untuk tepung pisang raja tanpa fermentasi dan $2732.4 \mathrm{Kcal} / \mathrm{kg}$ produk fermentasi. Hasil uji t-student menunjukan bahwa penggunaan tepung kulit pisang raja hasil fermentasi dalam ransum broiler memberikan pengaruh berbeda nyata $(\mathrm{P}<0,05)$ terhadap nilai AMEn. Dengan pengertian bahwa penggunaan tepung kulit pisang raja fermentasi dengan Rhizopus oligosporus memberikan hasil lebih tinggi dibandingkan dengan energi metabolis ransum yang mengandung kulit pisang raja tanpa fermentasi. Meningkatnya nilai energi metabolis kulit pisang raja diduga sebagai akibat terdegredasinya zat-zat makanan kompleks menjadi lebih sederhana yang pada akhirnya lebih muda dicerna. Penggunaan tepung kulit pisang raja produk fermentasi dengan Rhizopus oligosporus dalam ransum meningkatkan nilai AMEn ayam broiler. Umumnya bahan yang mengalami proses fermentasi memiliki kualitas yang lebih baik dibandingkan dengan bahan asalnya (Fardiaz, 1988). Selanjutnya, Bahri dan 
Rusdi (2008) menyatakan bahwa tingkat energi metabolis berhubungan erat dengan kecernaan dan penyerapan zat-zat makanan. Mc Donald et al. (2010) menyatakan bahwa daya cerna merupakan faktor yang mempengaruhi energi metabolis pakan dan daya cerna yang rendah menyebabkan banyak energi yang hilang melalui ekskreta, sebaliknya daya cerna yang tinggi menyebabkan energi hilang melalui ekskreta sedikit. Jumlah serat kasar yang tidak tercerna mempunyai hubungan dengan nilai energi metabolis, karena serat kasar yang tidak tercerna akan membawa sebagian nutrien lain yang tercerna ikut keluar bersama ekskreta. Berdasarkan hasil penelitian ini perbedaan nilai energi metabolis ransum yang menggunakan tepung kulit pisang raja produk fermentasi mengalami perubahan kandungan energi metabolis dan protein, maka dapat dikatakan bahwa produk fermentasi tersebut memiliki kualitas yang jauh lebih baik dari bahan asalnya.

\section{KESIMPULAN}

Berdasarkan hasil penelitian ini disimpulkan bahwa penggunaan kulit pisang raja produk fermentasi dengan Rhizopus oligosporus dalam ransum broiler dapat meningkatkan konsumsi protein, retensi nitrogen, dan energi metabolis ayam broiler.

\section{DAFTAR PUSTAKA}

Achi, O. K. 2005. The potential for Upgrading Traditional Fermented foods through biotechnology. African Journal of Biotechnology 4(5): 375380.

Bahri, S. dan R. Rusdi. 2008. Evaluasi energi metabolis pakan lokal pada ayam petelur. Jurnal Ilmu-Ilmu Pertanian 15(1): 75- 78

Buckle, K. A., R. A. Edwards, G. H. Fleet dan M. Wotton. 2007. Ilmu Pangan. Penerjemah: Hari Purnomo dan
Adiono. Universitas Indonesia. Jakarta.

Dewi, R. S. dan S. Aziz. 2011. Isolasi Rhizopus oligosporus pada beberapa inokulum tempe di Kabupaten Banyumas. Molekul 6(2): 93-104.

Dengah, S. P., J.F. Umboh, C.H. Rahasia dan Y.H.S. Kowel. 2013. Tepung maggot (Hermetia illucens) dapat mengantikan tepung ikan sebesar $75 \%$ atau $11,25 \%$ dalam ransum tanpamemberikan efek buruk terhadap efisiensi penggunaan makanan ayam broiler. Jurnal Zootek 36(1): 51-60.

Djapili, D., F. Wolayan, I. Untu dan H. Liwe. 2016. Pengaruh penggantian sebagai jagung dengan tepung kulit pisang raja (Musa Paradisiaca) dalam ransum terhadap Performan broiler. Zootec 36(1): 158-166.

Ewing, W. R. 1963. Poultry Nutrition.5th Ed. The Ray Ewing Company Publiser. Pasadena. California.

Fardiaz, S. 1988. Fisiologi Fermentasi. Bogor: Pusat Antar Universitas Lembaga Sumberdaya Informasi. Institut Pertanian Bogor.

Gultom, S.M. dan H. Supratman. 2014. Pengaruh Imbangan Energi dan Protein Ransum Terhadap Bobot karkas dan bobot lemak abdominal ayam broiler umur 3-5 minggu. Student e-Journal 1(1): 15

Kowel, Y.H.S. 2007. Pengaruh Penggunaan Limbah Minyak Pengalengan Ikan dalam Ransum Terhadap Efisiensi Biologis dan Kualitas Karkas Broiler. Tesis. Universitas Sam Ratulangi. Program Pascasarjana. Manado.

McDonald., R.A. Edwards, J.F.D. Greenhalgh, C.A. Morgan, L.A. Sinclair dan R.G. Wilkinson. 2010. Animal Nutrition. 7th Ed. Prentice Hall, Pearson, Harlow, England.

Mide, M.Z. 2016. Pengaruh Penambahan tepung daun katuk (Saoropus Androgynus) dalam ransum berbasis pakan lokal terrhadap performans 
broiler. Buletin Nutrisi dan Makanan Ternak, 9(1).

Mokoolang, M.C., F.R. Wolayan, M.R. Imbar, W.L. Toar. 2017. Biokonversi kulit pisang raja (Musa paradisiaca) dengan Rhizopus oligosporus terhadap perubahan kandungan bahan kering, bahan organik dan protein kasar. Zootec 38(1): 56-65.

Nuramanah, E., H. Sholihin dan W. Siswaningsih. 2012. Kajian Aktivitas Antioksidan Kulit Pisang Raja Bulu (Musa paradisiaca L. var sapientum) dan Produk Olahannya. Jurnal Sains dan Teknologi Kimia, 4(1) 1-7..

Pramana, B. T. 2012. Pengaruh Imbangan Energi dan Protein Ransum terhadap Energi Metabolis dan Retensi Nitrogen Ayam Broiler. Students eJournal 1(1): 14

Steel, R.G.D. dan J.H. Torrie. 1995. Prinsip dan Prosedur Statistik. PT. Gramedia. Jakarta.

Sugiyono, S., N. Hindratiningrum, Y. Primandini. 2015. Determinasi energi metabolis dan kandungan nutrisi hasil samping pasar sebagai potensi bahan pakan lokal ternak unggas. Jurnal Agripet 15(1): 41-45.
Suprayudi, M. A., W. Dimahesa, D. Jusadi, M. Setiawati dan J. Ekasari. 2011. Suplementasi crude enzim cairan rumen domba pada pakan berbasis nabati dalam memacu pertumbuhan ikan nila (Oreochromis niloticus). Jurnal Iktiologi Indonesia 11(2): 177-183.

The, F., J.S. Mandey, Y.H.S. Kowel dan M.N. Regar. 2017. Nilai retensi nitrogen dan energi metabolis broiler yang diberi ransum tepung limbah sawi putih (Brassica rapa L. subsp. pekinesis). Jurnal Zootek 37(1): 4149.

Tillman, A. D., H. Hartadi, S. Reksohadiprodjo, S. Prawirokusumo dan S. Lebdosoekojo. 1998. Ilmu Makanan Ternak Dasar. Gadjah Mada University Press, Yogyakarta.

Wahju, J. 2004. Ilmu Nutrisi Unggas. Yogyakarta: Gadjah Mada University Press.

Zarei, A. 2006. Apparent and true metabolizable energy in artemia Meal. Int. J. of Poult. Sci. 5(7): 627628 